\title{
Management of estuarine beaches on the Amazon coast though the application of recreational carrying capacity indices
}

Rosigleyse Corrêa de Sousa ${ }^{a}$, Luci Cajueiro Carneiro Pereira ${ }^{\mathrm{b}, 1}$, Rauquírio Marinho da Costa $^{c^{*}}$, José A. Jiménez ${ }^{d}$

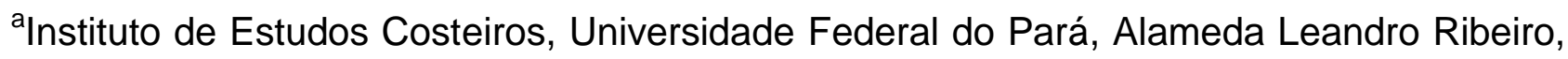
s/n, Aldeia, 68600-000, Bragança, Pará, Brazil. Email: rosigleyse@yahoo.com.br

'Laboratori d'Enginyeria Marítima, Universitat Politècnica de Catalunya- BarcelonaTech, c/Jordi Girona 1-3, Campus Nord ed D1, 08034 Barcelona, Spain. E-mail: cajueiro@ufpa.br.

IInstitut de Ciències del Mar (ICM/CSIC). Passeig Marítim de la Barceloneta, 37-49. E08003 Barcelona (Espanya). E-mail: raucosta@ufpa.br.

'Laboratori d'Enginyeria Marítima, Universitat Politècnica de Catalunya- BarcelonaTech, c/Jordi Girona 1-3, Campus Nord ed D1, 08034 Barcelona, Spain. E-mail: jose.jimenez@upc.edu.

\section{ACKNOWLEDGMENTS}

This study was financed by CAPES (Pro-Amazonas, number 3290/2013 and Ciências do Mar II, 43/2013), by CNPq (Universal, 483913/2012-0) and by PROPESP/UFPA/FADESP (PAPQ, 01/2015). The authors Sousa (141551/2012-7), Pereira (310909/2014-7 and 200629/2014-0) and Costa (309527/2014-7 and 200622/2014-5) would like to thank CNPq for research grants. Sousa would also like to thank CAPES for a PhD sandwich scholarship (8337/13-6). We are also indebted to Dr. Stephen Ferrari for his careful revision of the English.

\footnotetext{
${ }^{1}$ Corresponding Author: L. C. C. Pereira. E-mail adresses: cajueiro@ufpa.br, luci.pereira@pq.cnpq.br Permanent address: Instituto de Estudos Costeiros, Universidade Federal do Pará, Alameda Leandro Ribeiro, sn, Aldeia, 68600-000, Bragança, Pará, Brazil. Ph: 5591 34251209. Fax: 559134251593.
} 


\section{Highlights}

- A specific approach based on the RCC model was adopted for estuarine beaches;

- Local human pressures have impacted both the quality of the beaches and their carrying capacity;

- The principal problems are a lack of infrastructure or a public sanitation system;

- Major investments in services are needed to guarantee the recreational experience;

- The specific methodology adopted in this study can be used for other Amazon beach. 


\section{Introduction}

The use of the term carrying capacity in tourism has its origins in the 1960s (Coccossis and Mexa, 2004), to refer to the limits on the numbers of visitors that a tourist attraction can support. Over the past three decades, the growing interest in areas of tourism, such as beaches, has led to the elaboration of the Recreational Capacity Carrying (RCC) conceptual approach to support the development of management plans. Many variables have been used to define the $R C C$, including the biophysical limits of the environment, its numerical capacity, and the quality of the visitor experience (Saveriades, 2000, Coccossis et al., 2002; Saarinen, 2006). The most widely-used definition of the RCC is the maximum number of people that may visit a tourism destination at the same time without causing the degradation of the physical, economic and socio-cultural environment or any unacceptable decrease in the quality of the satisfaction of visitors (WTO, 1981).

The definition of the carrying capacity of recreational areas has become an essential tool for beach management, as it "enables the preservation of the high quality and quantity of coastal resources whilst meeting not only the current needs, but also securing long-term economic and ecological benefits for future generations" (UNEP/PAP, 1997), leading to an extensive literature in recent years, with a worldwide focus. As the $\mathrm{RCC}$ is used to evaluate problems related to overcrowding, these scientists have all been asking the same question - in scientific terms, how many visitors are "too many" for this beach?

In this context, carrying capacity assessment is a technique commonly used in beach management, being applied in different ways and in distinct socio-ecological settings and some recent examples of its application are provided below. De Ruyck et al. (1997) estimated the social carrying capacity from the opinion of users interviewed on King's Beach and Hobie Beach in South Africa. Silva (2002) combined physical and social carrying capacity assessments by using aerial photographs, video images and interviews 
1 with beachgoers in Sines (Portugal). Botero et al. (2008) developed a model

2 to calculate carrying capacity based on environmental support, urban infrastructure and

3 tourist services, which was used to assess five Caribbean beaches in Colombia. Jurado et

4 al. (2012) developed an approach to evaluate the growth limits of tourist destinations using

5 a mathematical formula based on integrated RCC indices, which were applied to two

6 scenarios of sustainability, one weak and one strong on the eastern Costa del Sol, Spain.

8 have been undertaken at a number of sites on the eastern and southern Brazilian coast

9 (e.g., Cordeiro et al., 2012; Polette \& Raucci, 2003; Silva et al., 2008), although only

10 limited research has been conducted on Amazon beaches (Silva et al., 2011a; Sousa et

11 al., 2011, 2014; Pessoa et al., 2013), and these studies have focused on oceanic beaches,

12 rather than estuarine ones. Located on the Brazilian Amazon coast, the littoral of Pará

13 state encompasses major estuarine systems and one of the World's largest and best

14 preserved mangrove forests (Souza-Filho et al., 2006). The local landscapes are highly

15 valuable in both ecological and esthetic terms, and both oceanic and estuarine beaches

16 are important recreation areas (Pereira et al., 2014; Sousa et al., 2014). Over the past few

17 decades, the construction of access roads has resulted in the increasing use of the

18 beaches for recreational activities, and tourism has become one of the principal sources of

19 income for the local economy, especially during the vacation periods (Pereira et al., 2007;

20 Szlafsztein, 2009; Szlafsztein \& Sterr, 2007).

21 Unfortunately, almost 30 years after the implementation of federal law number

22 7661, which established the National Coastal Management Plan, and with many state

23 coastal management plans in force, few practical measures have been taken to minimize,

24 prevent and/or solve the conflicts associated with the use of land along the coast of Pará.

25 As the popularity of the state's beaches has grown exponentially in recent years, the need 
1 for coastal zoning and management plans - including the monitoring of RCC indicators -

2 has become increasingly urgent.

An RCC approach is important here because, while these coastal environments are

4 still relatively well-preserved, its beaches already lack sufficient infrastructure and services

5 to satisfy current levels of demand (Pereira et al., 2014). Unplanned and uncontrolled

6 development has resulted in social and economic conflicts, as well as the deterioration of

7 local coastal resources (Oliveira et al., 2011; Pinto et al., 2011; Silva et al., 2011b; Sousa

8 et al., 2013).

In this context, the principal aim of this study was to contribute to the improved management of the beaches in this estuarine environment using the Recreational Carrying

11 Capacity (RCC) concept. To this end, we adapted the standard RCC model to provide a

12 combined assessment of natural and anthropogenic factors considering the unique 13 characteristics of this type of beach. In general terms, it is extremely difficult to determine 14 the "magic number" of tourists because the threshold established by tourists tends to differ 15 from the ecological limits (Jurado et al., 2012), but we adopted a specific approach for 16 these estuarine beaches that can also be used at other Amazon beaches.

\section{Amazon estuarine beaches}

Estuarine beaches typically have a relatively long shoreline in comparison with those on open coasts, and are affected primarily by tidal currents, with negligible wave

21 action (e.g., Nordstrom, 1992; Vila-Concejo et al., 2010), and are thus considered low energy environments. However, the beaches of the estuaries of the Amazon coast have

23 distinct characteristics, and do not necessarily conform to the classification system 24 adopted by Jackson et al. (2002) 2 .

\footnotetext{
${ }^{2}$ Jackson et al. (2002) proposed four criteria to define low-energy beaches: (i) negligible significant wave heights $\left(H_{\mathrm{s}}<0.25 \mathrm{~m}\right)$ during non-storm conditions, (ii) low significant wave heights $\left(H_{\mathrm{s}}<0.50 \mathrm{~m}\right)$ during strong onshore winds, (iii) narrow beach face width $(<20 \mathrm{~m}$ in microtidal environments) and (iv) morphological features that may include those inherited from higher energy events.
} 
Amazon estuarine beaches are located within a mangrove-dominated fluvial-marine

ecosystem controlled by meso- and macrotides, waves of moderate energy and strong tidal currents. The climate of the study region is humid equatorial with a mean annual temperature of $26-27^{\circ} \mathrm{C}$ and annual precipitation generally between 2000 and $3000 \mathrm{~mm}$, with $75-85 \%$ of this precipitation falling during the rainy season, between January and May, and a dry season during the second half of the year (INMET, 2015).

The enormous fluvial discharge observed in this area is the result of the region rainfall pattern, which generates a massive input of suspended particulate matter (such as suspended sediments, detritus and organisms) and stained dissolved organic matter (humic substances) from the extensive areas of mangrove. Tide-dominated conditions and strong local tidal currents are responsible for the resuspension of the fine particulate matter contributing to much higher turbidity levels (> $100 \mathrm{NTU}$ ) in the coastal waters, including the estuarine beaches. The enormous fluvial discharge from the Amazon River and adjoining estuaries, which represents $20 \%$ of the planet's freshwater, results in the typically reduced salinity (near zero) of the region's estuarine beaches, especially during rainy season.

The tidal range reaches a maximum of $11 \mathrm{~m}$ at Igarapé do Inferno (Amapá), decreasing northwards along the Amapá coast to $7 \mathrm{~m}$ and then $4 \mathrm{~m}$, and 5-6 $\mathrm{m}$ to the south on the Pará coast, 3-4 m in Marajó Bay and at Belém, rising eastwards to $7 \mathrm{~m}$ in the Gulf of Maranhão, and then declining again to $3 \mathrm{~m}$ at the Parnaíba delta (DHN, 2015). Local values of tidal elevation together with estuarine geomorphology determine local tidal current patterns. Strong tidal currents affect the estuarine beaches and can reach velocities of more than $2.0 \mathrm{~m} \mathrm{~s}^{-1}$ (Beardsley et al., 1995). Offshore significant wave heights can reach more than $1.5 \mathrm{~m}$, but the influence of the tides normally prevails over wave action, especially at low tide, when the estuarine waters are sheltered by sandbanks, which reinforce the tidal modulation. 
In contrast with other parts of Brazil, the principal recreational period on the Amazon

2 coast coincides with the July school vacation and bank holidays during the second half of

3 the year, given that the January school vacation - the peak period in most other Brazilian

4 regions - coincides with the beginning of the Amazon's long and intense rainy season.

5 Other factors, such as the relative isolation of the beaches due to extensive area of

6 mangrove forest, the difficult access due to presence of countless estuaries, creeks and

7 rivers, and the low quality of the available services and infrastructure, combine to limit the

8 development of the coastal tourism industry.

As a result, only a reduced number of the region's beaches have been used

11 combined with a lack of urban/land-use planning, on these few beaches has increased

12 considerably during the past few decades, generating serious environmental and social 13 issues (Szlafsztein, 2012). These impacts have been affecting the local coast, altering the 14 conditions expected by different interest groups (local residents, business owners, 15 fishermen, beachgoers) for recreational or economic activities. within the intertidal zone (as at Marudá and Murubira beaches). This situation has negative 18 repercussions on the quality of the beach water, especially during the summer vacation 19 period (July). The presence of sewage outfalls have resulted in a number of polluting 20 effects, including unpleasant sights and odors, as well as contamination by bacteria, such 21 as thermotolerant coliforms.

\section{Study Area}

The study area is located on the Amazon Macrotidal Mangrove coast of the coastal zone of Pará. It comprises three beaches, Colares, Murubira and Marudá (Figure 1). This coastal sector has a highly indented shoreline consisting of bays and associated tidal 
1 creeks and their tributaries, which form funnel-shaped estuaries. The bays are filled with

2 mangrove forests, and estuarine beaches are tide-dominated and fronted by extensive

3 intertidal sand- and/or mudflats (Pereira et al., 2016). Colares (mesotidal) and Marudá

4 (macrotidal) beaches are characterized by muddy sediments in the areas not affected by

5 wave action. Located on Colares Island, Colares beach is $96 \mathrm{~km}$ far from the state capital,

6 Belém. The island is separated from the continent by the Guajará-Mirim River and the

7 Laura tidal creek, and the beach is located in a sheltered portion of the island. This sandy

8 beach is $561 \mathrm{~m}$ long and reaches a width of $400 \mathrm{~m}$ during the low spring tides. Due to the

9 influence of the local fluvial conditions, salinity varies between 1 and 5 . Marudá beach is

$10160 \mathrm{~km}$ from Belém, at the mouth of the Marapanim estuary. This beach is more exposed

11 to wave action $\left(H_{\mathrm{s}}\right.$ normally above $1.0 \mathrm{~m}$ ) and marine waters (salinity 18-28), with a tidal

12 range of up to $5 \mathrm{~m}$. This beach extends for more than $1 \mathrm{~km}$ and has a width of around 300 13 m during the low spring tide.

14 Murubira beach is located on Mosqueiro Island, $72 \mathrm{~km}$ from Belém. This beach is a 15 site of considerable historic and touristic importance for the Brazilian state of Pará. 16 Located on the margin of the Pará River (Marajó Bay), Murubira beach is separated from 17 the continent by the Maguari and Marinhas creeks, and by Sol Bay. The tidal elevation in 18 this beach is of $3.5 \mathrm{~m}$ during spring tides $(\mathrm{DHN}, 2015)$, and wave height $\left(H_{\mathrm{s}}\right)$ may reach $191.5 \mathrm{~m}$ (El-Robrini et al., 2006). The beach is $1.4 \mathrm{~km}$ long and around $70 \mathrm{~m}$ wide during low 20 spring tides.

In spite of being in an area of considerable natural and ecological value, these 22 beaches are used intensively for recreational purposes, resulting in extensive 23 modifications of their original natural status. Currently, Murubira and Marudá can be 24 considered to be semi-urban beaches, with promenades and other infrastructure, while 25 Colares can be classified as a rural beach, with well-preserved natural features, including 26 native vegetation and dunes on the backshore. 
Due to the local meso/macrotides, the beach profiles can vary from hundreds of

2 meters (low-tides) to a few meters (high tides). Thus, at the end of the flood tide, high tide

3 and the beginning of the ebb tide, many of the beachgoers frequent bars and restaurants

4 or foreshore areas because the backshore area is negligible.

5

$6<$ Insert Figure 1>

\section{Data and Methods}

Given the objectives of this study, two main approaches were adopted: (i) the

10 qualitative and quantitative characterization of environmental conditions and services, i.e.,

11 the status of the beach, and (ii) the calculation of a recreational carrying capacity index

12 based on an integrated assessment of the physical area of the beach, its natural 13 conditions, and its facilities. determined using the basic approach of Cifuentes (1992), as modified by Cifuentes et al.

18 (1999), Segrado et al. (2008), and Zacarias et al. (2011). This approach attempts to establish the maximum number of visitors that can be tolerated in an area based on current physical and natural conditions together with management practices.

Following the approach of Zacarias et al. (2011), we aimed to obtain the recreational carrying capacity $(\mathrm{RCC})$ of the estuarine beaches, based on its physical 23 carrying capacity (PCC), modulated by a series of correction factors which are defined here as a function of the intrinsic characteristics of the study beaches as: 
2 where, $W Q=$ water quality, $E n v Q=$ environmental quality, $E Q=$ ecological quality, and $Q S$ 3 = quality of services, which are described below. These four modulation indices cover the main factors that influence the overall

quality of the system and they were selected to adjust the PCC (which should represent

6 the maximum capacity of the system) in such a way as to provide an RCC that reflects

7 actual conditions. The range of values of this index was selected in an attempt to establish

8 an equilibrium between the low level of services expected on a beach in a natural

9 environment and the services demanded by beachgoers when using a beach, even in

10 areas dominated by highly natural environments. We have thus established a reduction of

$1140 \%$ in the RCC for beaches on which no services are available, with a much higher value

12 being considered in the case of urban beaches. The range of values should nevertheless

13 be established specifically for each beach, based on an analysis of the demands and

14 requirements of users, even though this may emphasize the need for more services. that can be supported by the beach. It is obtained by:

$P C C=A / A_{u}$ where, $A$ is the usable area of the study beach, and $A_{u}$ is the area available per user. The value of $A$ is obtained for each beach by measuring the area occupied by visitors. Given the local mesotidal (tidal range between 2 and $4 \mathrm{~m}$ ) or macrotidal (tidal range $>4 \mathrm{~m}$ ) conditions, the beach mean width was calculated by taking into account the 
1 difference between high and low tides (Figure 2). At Colares and Marudá, the lower sector

2 of the intertidal area was not included in the usable area due to presence of muddy

3 sediments which prevented the use of this area by visitors.

4

$5<$ Insert Figure 2>

6

8 development of each beach into account. According to their characteristics, Marudá and

9 Murubira were classified as semi-urban beaches and Colares as a rural beach. To assign

10 the corresponding $A_{u}$ value we used values reported in the literature for these types of

11 beach (Embratur, 1975; De Ruyck, 1997; Silva, 2002) as well as field data. Based on this,

$12 A_{u}$ was defined as $10 \mathrm{~m}^{2} /$ visitor for the semi-urban beaches and $12 \mathrm{~m}^{2} / \mathrm{visitor}$ for the rural 13 beach.

\subsubsection{Correction factors}

The correction factors or the PCC considered in this study were selected to account

17 for the principal factors affecting the recreational use of the beaches in the Amazon region.

18 The relative weight of each factor was scaled taking into account their expected influence 19 based on published studies and the results of local surveys (July 2012 and 2013). These 20 factors are presented below.

\section{(i) Water quality $(W Q)$}

This correction factor refers to the water quality of the beach in terms of its potential

24 effects on the health of visitors. Beach water is susceptible to bacteriological

25 contamination which may result in exposure to public health risks during bathing.

26 Thermotolerant coliforms were used to evaluate water quality because these bacteria are 
1 considered to be indicators of contamination by sewage, which can cause gastroenteritis,

2 and other health problems, such as respiratory, skin, eye and ear complaints (Fewtrell and 3 Kay, 2015).

The index was divided into four categories, according to the Most Probable Number 5 (MPN) of fecal coliforms per $100 \mathrm{~mL}: 1.0$ (Excellent, <250 MPN $100 \mathrm{~mL}^{-1}$ ), 0.8 (Very good, 6 250-500 MPN $100 \mathrm{~mL}^{-1}$ ), 0.3 (Satisfactory, 500-1000 MPN $100 \mathrm{~mL}^{-1}$ ) to 0 (Inappropriate, $7>1100 \mathrm{MPN} 100 \mathrm{~mL}^{-1}$ ) based on the criteria established by Brazilian National Environment 8 Council (CONAMA, 274/2000) for water destined for human bathing.

(ii) Environmental quality (EnvQ)

This index reflects the environmental status of the water for bathing, except for the bacteriological component, which is measured by the $W Q$ index. The EnvQ index has two components, (i) the physicochemical characteristics of the water, and (ii) the aesthetic quality of the sand and water. Each of these components is composed of a number of specific parameters based on the criteria established by CONAMA (357/2005) for bathing water. The final value of the EnvQ is given by the mean combined value of these two components. As the effects of this variable on human health are considered negligible, and most affect the beachgoer's comfort and perceptions, this index was scored between 1.0 (no effect) and 0.6 (maximum effect on users' perceptions).

\section{Physicochemical variables}

The score for this component was calculated by measuring a series of physicochemical variables of the water. To select the critical value for each of these variables, we used the criteria of CONAMA to classify the quality of the water as good or bad. The value of this component was obtained by the simple average of the different variables. 
The limits for physicochemical parameters by COMAMA are: $\mathrm{pH}$ of $6.5-8.5$,

2 dissolved oxygen $>5.0 \mathrm{mg} \mathrm{L}^{-1}$, nitrite $<0.07 \mathrm{mg} \mathrm{L}^{-1}$, nitrate $<0.4 \mathrm{mg} \mathrm{L}^{-1}$ and total

3 phosphorus $<0.124 \mathrm{mg} \mathrm{L}^{-1}$. A score of 0.6 was attributed to the upper and/or lower limit

4 values, according to the criteria established by CONAMA, and 1.0 when the limits of

5 tolerance were exceeded. These variables were chosen because they are good indicators

6 of natural and anthropogenic changes in water, and they have been previously used for

7 this purpose (e.g. Praveena et al., 2013; Silva et al., 2013). The parameters are well

8 documented. For example, (i) lower $\mathrm{pH}$ levels are known to cause eye and skin irritations,

9 and even a slight change may result in the death of some aquatic organisms; (ii) the

10 excessive input of nutrients through the discharge of sewage leads to eutrophication,

11 which provokes algal blooms, and (iii) the proliferation of algae can lead to the depletion of

12 dissolved oxygen, which is consumed by bacteria during the oxidative decomposition of

13 the organic matter produced by the die-off of the algae.

Visual aspects

The aesthetic quality was based on the absence of oils and fats, floating debris,

17 solid residues in the sand, sand odors, and water turbidity. However, these conditions are

18 rarely found on the Amazon coast where the estuarine and coastal waters are affected by

19 the suspended matter discharged by the many local rivers, which also transport a

20 significant amount of vegetation debris (Pereira et al., 2012, 2013a). Although this does

21 not necessarily imply that water quality will be poor in these environments, we also

22 considered these aspects to be undesirable for beachgoers given that, even in this

23 environment, they have negative attitudes towards these conditions. In this context, the

24 parameters were based on CONAMA, and represent an important indicator of the

25 recreational experience of beachgoers and the visual quality of the beaches. 
The score for this component was calculated by integrating the contribution of these

2 five parameters referring to the aesthetic quality of the beach and users' comfort. The

3 CONAMA criteria (357/2005) require negligible water turbidity, no floating debris, and no

4 residues in the sand. All the variables were measured qualitatively (present or absent)

5 and, as in the previous case, the criteria provided by CONAMA were used to establish the

6 corresponding value (0.6, present or 1 , absent). The integral value for this component was

7 obtained from the simple average value of each variable.

(iii) Ecological quality $(E Q)$

This indicator measures the status of the natural conditions of the beach that, when

11 affected, may represent the degradation of the resource. In this sense, it implicitly

12 assumes that the RCC represents the maximum potential use of the beach any

13 degradation of its natural conditions. This variable is presented as an index with a score 14 ranging between 1 (no effect on natural conditions) to 0.6 (natural conditions degraded).

According to typical conditions of the study area, three components (degradation of dunes, degradation of mangroves and the risk of coastal erosion) were taken into account

17 through direct observation, and were scored as high (0.6), moderate (0.8) and low (1.0).

18 The overall score of this component was obtained as the simple average of the variables 19 considered.

$21 \quad$ (iv) Quality of services (QS)

In spite of the fact that these beaches are located in a natural environment (semiurban or rural) they are popular with beachgoers, and regular visitors demand specific 24 services during their stay. Given this, planning the recreational use of the coast where beaches are used intensively must take the quality of the services provided into account, considering that a minimum level of services is required to avoid the collapse of the 
1 resource, in recreational terms. Based on the local conditions, a minimum set of services

2 was considered essential for the recreational use of the local beaches - public restrooms, 3 waste bins, parking, accommodation, bar and restaurants, and accessibility. The overall

4 QS score for each beach was given by the mean value of the components evaluated, with

5 a final score of between 0.6 and 1.0 , with 0.6 referring to the absence of the service, 0.8

6 for present but unsatisfactory, and 1 when it is adequate. The qualitative assessment was

7 based on visual observations and surveys of beachgoers.

\subsection{Beach Status (environmental conditions and services)}

The procedures used to assess the qualitative and quantitative features of the

11 environmental conditions and available services for the calculation of the RCC are

12 summarized in Table 1.The services available at each beach were evaluated in situ during

13 the vacation season using a checklist, and photographs were taken of specific features.

14 Environmental conditions were measured in field campaigns during the vacation season.

15 Each beach was surveyed on a Sunday (peak visitation day) during three weeks in July 162012 and July 2013. Surface water samples were collected every three hours between

17 07:00 $\mathrm{h}$ and 19:00 h using $5 \mathrm{~L}$ Niskin oceanographic bottle (General Oceanics). These 18 samples were used to determine the $\mathrm{pH}$ of the water, dissolved oxygen and nutrient 19 concentrations, and thermotolerant coliform levels. Thermotolerant coliforms were also analyzed in samples of water collected from the Sonrisal stream on Colares beach.

In the laboratory, dissolved oxygen was determined by the Winkler method, as 22 modified by Strickland and Parsons (1968) and $\mathrm{pH}$ was measured using a pHmeter 23 (Hanna HI 2221). Thermotolerant coliform levels were determined using the method of the 24 American Public Health Association (APHA, 2012). The water samples were vacuum25 filtered through glass-fiber filters (Millipore GF/F $0.7 \mu \mathrm{m}, 47 \mathrm{~mm}$ ), and then freeze-dried for dissolved nutrient analyses. Dissolved inorganic nutrient (nitrite $-\mathrm{NO}_{2}$ and nitrate $-\mathrm{NO}_{3}$ ) 
1 concentrations were determined by spectrophotometry, following the procedures described

2 by Strickland and Parsons (1977) and Grasshoff et al. (1983). Filtered water samples were

3 also frozen for the subsequent analysis of dissolved total phosphorus (TP) by applying an

4 adaptation of the simultaneous oxidation of nitrogen and phosphorus compounds using an

5 alkaline persulfate oxidizing solution (Grasshoff et al., 1999).

6

$7 \quad<$ Insert Table 1>

9 5. Recreational Carrying Capacity of the Study Beaches

\subsection{Physical Carrying Capacity}

Table 2 shows the total and usable areas of the three study beaches. The beach with the largest surface area is Marudá, with $123,900 \mathrm{~m}^{2}$, adjusted to $93,763 \mathrm{~m}^{2}$ by tidal modulation, and further reduced to a final usable area of $67,113 \mathrm{~m}^{2}(54 \%$ of the base value) by the presence of muddy sediments in the intertidal zone. After corrections, the usable area of Colares beach is $27,825 \mathrm{~m}^{2}$ ( $53 \%$ of the total surface area), and that of Murubira beach is $16,000 \mathrm{~m}^{2}(71 \%$ of the total area). Murubira is the only one of the three

17 beaches with no muddy sediments in the intertidal area.

To convert these areas into numbers of users, different densities were considered

19 for semi-urban (10 $\mathrm{m}^{2} /$ visitor) and rural (12 $\mathrm{m}^{2} /$ visitor) beaches. The PCC is thus 6711 20 visitors for Marudá, 2319 for Colares, and 1600 for Murubira without considering the

21 rotation factor, which takes into account the average length of the stay on the beach, for 22 which, unfortunately, there are no data. However, direct observations made during the 23 study period indicate that the beachgoers usually stay all day long on these beaches, i.e. 24 rotation is very low. 
The spatial distribution of the users on each beach was determined primarily by

3 three main factors, i.e. tidal range, accessibility and the occurrence of cultural events.

4 Thus, the following main characteristics were observed:

5 (i) Most of the visitors on Colares and Marudá beaches were located at a distance of

6 more than $100 \mathrm{~m}$ from the sea and less than $30 \mathrm{~m}$ from the main beach access (Figure $73 \mathrm{~A})$.

8 (ii) The distribution of beachgoers at Colares and Marudá and the carrying capacity of

9 the intertidal sector depend on the tidal range (Figure 3B).

10 (iii) The promenade at Murubira beach was more densely occupied than the other 11 beach sectors (Figure $3 \mathrm{C}$ ). This sector is occupied primarily by younger beachgoers 12 attending social events (street parties and shows) which are usually organized in this area.

$14<$ insert Figure 3>

5.2 Correction factors

During the survey period, in spite of the large number of people visiting the study

18 beaches, the water quality $W Q$ was unsatisfactory at Marudá (0.00), although it was good

19 at Murubira (0.3) and Colares (0.8) beaches (Tables 2 and 3). The highest concentration

20 of thermotolerant coliforms was recorded at Marudá, with more than half of the water

21 samples exceeding the CONAMA limit for human use (> $\left.1100 \mathrm{MPN} 100 \mathrm{~mL}^{-1}\right)$. At the

22 opposite extreme, Colares presented the lowest level of microbiological contamination with

23 only $20 \%$ of the water samples being contaminated by thermotolerant coliforms (> 1100

24 MPN $100 \mathrm{~mL}^{-1}$ ). These levels of bacterial contamination are correlated with the presence

25 of sewage outlets discharging directly on the beach, with 7,10 and 2 outfalls $/ \mathrm{km}$ on

26 Marudá, Murubira and Colares beaches, respectively. At Colares, part of the observed 
1 contamination may be determined by the discharge of the Sonrisal stream, which had high

2 thermotolerant coliform concentrations (>1100 MPN/100 $\left.\mathrm{mL}^{-1}\right)$.

3

$4<$ Insert Table 3>

5

$21<$ Insert Table 4>

$22<$ Insert Figure 4> garbage collection.

When analyzing the quality of services (QS), Colares beach obtained the lowest

All the study beaches obtained satisfactory scores for the environmental quality (EnvQ) index (according to CONAMA standards), with values of 0.95 being recorded for Colares, and 0.85 for Marudá and Murubira beaches (Tables 2 and 3). Despite this, a number of aspects of the visual quality of these beaches were evaluated negatively, including sewage outfalls, trash in the water, and turbidity. The accumulation of trash leads to an unpleasant odor, especially at Marudá and Murubira, where social events are frequent. This problem is exacerbated by the lack of public restrooms and infrequent

The ecological quality $(E Q)$ of Colares beach was considered to be excellent $(0.87)$, due to the good preservation of its natural environment, dominated by dunes. On the other hand, Marudá (0.67) and Murubira (0.73) were classified as regular (Tables 2 and 4). In the study area, especially Marudá and Murubira beaches, many bars, restaurants and hotels have been constructed on the dunes, affecting $70-80 \%$ of the coastline, with major impacts on the local mangroves and coastal restinga vegetation (Figure 4). score $(0.71)$ due to its lack of services, while only slightly higher scores ( 0.80 in each case) were obtained for Murubira and Marudá beaches. Overall, the three study beaches 
1 presented severe limitations in terms of the basic services requires for recreational

2 activities (Tables 2 and 5).

3 Finally, when the correction factors are applied to the PCC scores for the study

4 beaches the RCC scores decrease significantly in all cases. The most significant

5 modification was observed in the case of Marudá beach which, despite having the highest

6 PCC score, received an RCC score of zero, due to the inadequate quality of the water,

7 which was found to be unfit for human use. In this case, the analysis found that the beach

8 should not be used for recreational purposes. In the case of Colares and Murubira

9 beaches, the RCC scores also decreased significantly, reaching values of 1089 visitors at

10 Colares (about $47 \%$ of the original score) and 238 at Murubira (15\%). These final RCC

11 scores indicate a low carrying capacity, given that most of the necessary infrastructure and

12 services are not provided.

13

$14<$ Insert Table 5>

\section{Implications for beach management}

The Recreational Capacity Carrying $(\mathrm{RCC})$ is an important tool for beach

18 management when the aim is to enhance the recreational potential of a coastal

19 environment. While the dimensions of the beach - which determine the available space -

20 are a major component of this index, it is also modulated by variables related to the

21 "quality of the visit", and the "preservation of the resource". In this study, we adopted an

22 RCC approach to provide management recommendations for Amazonian estuarine

23 beaches. While these environments contain valuable natural resources that must be

24 preserved, they are being used increasingly by local populations for recreational purposes.

25 As a consequence, adequate management is needed to maintain this natural resource, 26 which demands a recreational carrying capacity assessment. The analysis conducted here 
1 has shown that, while these rural/semi-urban beaches are still rich in natural resources,

2 increasing and unregulated human pressure has resulted in a significant decrease of the

3 quality of the beaches and, thus, of their carrying capacity.

As mentioned above, the methodological approach used in the present study is an adaptation of a standard RCC assessment protocol, which was modified specifically for the evaluation of estuarine beaches of the Amazon region. To this end, we need to take into account local environmental and social conditions to select adequate indicators for the modulation of the RCC, as well as to define their upper and lower limits. In this study, the

9 proposed scale for the correction factors was based on previous studies of user 10 preferences, together with Brazilian standards of environmental quality (see Methods). The

11 final RCC values obtained by this approach will depend on the scale selected and in this 12 sense, the definition of adequate parameters in essential for a reliable analysis. To apply 13 the same index to other environments, it would be necessary to create a unified scale of 14 correction factors, which would be derived ideally from an extensive study of the 15 requirements and preferences of users.

Of the three study beaches, Colares was the least contaminated, due to its

17 relatively undeveloped and natural conditions, with well-preserved dunes and mangroves.

18 This beach received high scores for all the indices except the quality of services, which are 19 mostly rudimentary or, in some cases, totally absent. This reflects its natural/rural character but emphasizes its inadequate potential for seasonal peaks of visitation. were due primarily to the large number of sewage outfalls and the bacteriological 23 contamination of the water used for recreational activities. Many other factors were also considered unsatisfactory at both beaches, including the undesirable odor of the sand and water, the highly turbid water, the presence of trash on the sand and debris floating in the water, the loss of dunes and mangroves, and the unregulated occupation of the coastline. 
1 The loss of mangroves and dunes has had knock-on effects such as an increase in coastal

2 erosion and the loss of habitat for endangered species. Recreational activities at Murubira

3 are threatened by the low RCC and the lack of investment in the infrastructure needed for

4 the collection and treatment of domestic waste. At Marudá, the situation was critical (RCC

$5=0$ ), and bathing must be banned due to the high levels of bacteriological contamination.

6 Unfortunately, the local authorities have not taken any measures to mediate this problem.

In Brazil, as in many other parts of the world, the lack of adequate infrastructure and services, and the unregulated occupation of many beaches, has produced an increasingly

9 negative effect on their attractiveness for beachgoers (Mohanty et al., 2008; Olsen, 2003;

10 Pereira et al., 2007; Botero et al., 2008). The results of the present study have

11 demonstrated the need for urgent government intervention (in particular, investments in

12 services and infrastructure) in order to improve the quality of the beaches and guarantee

13 the recreational experience of local beachgoers.

14 Based on the results of the present study, we can recommend a number of 15 measures that should be taken by local authorities to improve the status of the three

16 estuarine beaches surveyed: (i) the immediate interruption of any sewage outlet that 17 discharges effluents directly onto the beach or into nearby watercourses, (ii) the 18 construction of a public sanitation system and sewage treatment plants, (iii) the 19 establishment of a permanent water quality monitoring system for the beaches used for 20 bathing and other recreational activities, (iv) the installation of a refuse collection system, 21 including an increased number of waste bins and collection points, ( $v$ ) the immediate 22 prohibition of the construction of buildings on dunes or in areas of mangrove, and (vi) the 23 installation of public restroom facilities, especially during the peak vacation period. These 24 recommendations can be modified for other rural and semi-urban beaches in Brazil, and in 25 other regions of the world. 
In addition to these recommendations, the findings of the present study indicate the

2 need for the careful reassessment of many of the standard CONAMA criteria - such as

3 turbidity - used for the evaluation of water quality, given the unique conditions found on

4 the beaches of the Amazon coast. High turbidity, for example, is a typical condition caused

5 by the enormous amount of fluvial discharge and high energy local hydrodynamic

6 conditions (e.g., Pereira et al., 2012a, 2013a, 2013b). Clearly, then, many of the criteria

7 established by CONAMA require revision before being applied to the assessment of water

8 quality in areas of the Amazon coast, where estuaries are dominated by fluvial conditions

9 during the rainy season, and more coastal or marine conditions during the dry season.

11 REFERENCES

12 American Public Health Association (APHA), American Water Works Association (AWWA), 13 \& Water Environment Federation (WEF) (2012). Standard Methods for the Examination of 14 Water and Wastewater. (22nd ed.). Alexandria: Washington D.C.

15 Beardsley, R. C., Candela, J., Limeburner, R., Geyer, W. R., Lentz, S. J., Castro, B. M., 16 Cacchione, D., \& Carneiro, N. (1995). The M2 tide on the Amazon shelf. Journal of 17 Geophysical Research, 100 (C2), 2283-2319.

18 Botero, C., García, Y. H., Porto, J. G, Manjarrés, M. O., \& Rocca, L. H. D. (2008). 19 Metodología de cálculo de la capacidad de carga turística como herramienta para la 20 gestión ambiental y su aplicación en cinco playas del caribe norte Colombiano. Gestión y 21 Ambiente, $11(3), 109-122$.

22 Cifuentes, M. A. (1992). Determinación de capacidad de carga turística en áreas 23 protegidas. Costa Rica: Biblioteca Orton IICA/CATIE, 28p. Available in: 24 http://www.ulpgc.es/hege/almacen/download/23/23388/articulocifuentes.pdf. 
1 Cifuentes, M. A., Mesquita, C. A. B., Méndez, J., Morales, M. E., Aguilar, N., \& Cancino, D.

2 (1999). Capacidad de carga turística de las areas de Uso Público del Monumento

3 Nacional Guayabo, Costa Rica. Costa Rica: WWF Centro America.

4 Coccossis, H., \& Mexa, A. (2004). The challenge of Tourism Carrying Capacity

5 Assessment: Theory and Practice, Aldershot: Ashgate Publishing.

6 Coccossis, H., Mexa, A., \& Collovini, A. (2002). Defining, measuring and evaluating

7 carrying capacity in European tourism destinations. Environmental planning laboratory by

8 the European commission, directorate-general for environment, nuclear safety and civil

9 protection. http://ec.europa.eu/environment/iczm/pdf/tcca_en.pdf. Viewed at 2016. 113 pp.

10 CONAMA - Conselho Nacional de Meio Ambiente, Brasil. Resolução 274 de 29 de

11 novembro de 2000. Dispõe sobre a qualidade das águas de balneabilidade. Diário Oficial

12 da República Federativa do Brasil, 8 de janeiro de 2001. Available in: < 13 http://www.cetesb.sp.gov.br >.

14 CONAMA - Conselho Nacional de Meio Ambiente, Brasil. Resolução 357 de 17 de março 15 de 2005. Dispõe sobre a classificação dos corpos de água e diretrizes ambientais para o 16 seu enquadramento, bem como estabelece as condições e padrões de lançamento de 17 efluentes, e dá outras providências. Diário Oficial da República Federativa do Brasil. 18 Available in: < http://www.cetesb.sp.gov.br >.

19 Cordeiro, I. D., Korossy, N., \& Selva, V. S. F. (2012). Determinácion de la capacidade de 20 carga turística: el caso de Playa de Tamandaré-Pernambuco-Brasil. Estudios y 21 Perspectivas em Turismo, 21, 1630-1645.

22 De Ruyck, M. C., Alexandre, G. S., \& Mclachlan, A. (1997). Social carrying capacity as a 23 management tool for sandy beaches. Journal Coastal of Research, 13(3), 822-830.

24 DHN, Departamento de Hidrografia e Navegação. (2015). Tábuas de maré para o 25 fundeadouro de Salinópolis (Estado do Pará). http://www.dhn.mar.mil.br/chm/tabuas. 
1 El-Robrini, M., Silva, M. A. M. A. da, Souza-Filho, P. W. M., El-Robrini, M. H. S., Silva

2 Júnior, O. G. da, \& França, C.F. de. (2006). Pará. In D. Muehe, (Org.), Erosão e

3 progradação do litoral brasileiro (pp. 41-86). Brasília: Ministério do Meio Ambiente.

4 EMBRATUR (1975). Projeto Turismo - Normas para ocupação do território. Brasília:

5 Ministério da Indústria e Comércio.

6 Fewtrell, L., \& Kay, D. (2015). Recreational Water and Infection: A Review of Recent

7 Findings. Current Environmental Health Reports, 2, 85-94.

8 Grasshoff, K., Emrhardt, M., \& Kremling. E. K. (1983). Methods of Seawater Analysis. (2nd 9 ed.). New York: Verlag Chemie.

10 Grasshoff, K., Kremling, K., \& Ehrdardt, M. (1999). Methods of seawater analysis. (3rd ed.)

11 Wiley. - Weinheim; New York; Chiester; Brisbane; Singapore; Toronto: Wiley-VCH.

12 INMET (Instituto Nacional de Metereologia). 2015. Monitoramento de Estações 13 Automáticas. Available in: http://www.inmet.gov.br/sonabra/maps/automaticas.php.

14 Viewed 2 February 2015.

15 Jackson, N., Nordstrom, K., Eliot, I., \& Masselink, G. (2002). Low energy' sandy beaches 16 in marine and estuarine environments: a review. Geomorphology, 48, 147-162.

17 Jurado, E. N., Tejada, M. T., García, F. A., González, J. C., Macías, R. C., Peña, J. D., 18 Gutiérrez, F. F., Fernández, G. G., Gallego, M. L, García, G. M., Gutiérrez, O. M., Concha, 19 F. N., Rúa, F. R. de la, Sinoga, J. R., \& Becerra, F. S. (2012). Carrying capacity 20 assessment for tourist destinations. Methodology for the creation of synthetic indicators 21 applied in a coastal area. Tourism Management, 33, 1337-1346.

22 Mohanty, P. K., Panda, U. S., Pal, S. R., \& Mishra, P. (2008). Monitoring and management 23 of environmental changes along the Orissa Coast. Journal of Coastal Research, 24(2B), $24 \quad 13-27$.

25 Nordstrom, K. (1992). Estuarine Beaches. New York: Elsevier Science Publishers. 
1 Oliveira, S. M. O. de, Pereira, L. C. C., Vila-Concejo, A., Gorayeb, A., Sousa, R. C. de, \&

2 Costa, R. M. da (2011). Natural and anthropogenic impacts on a macrotidal sandy beach

3 of the Brazilian Amazon (Ajuruteua): guidelines for coastal management. Journal of

$4 \quad$ Coastal Research, SI 64, 1385-1389.

5 Olsen, S. B. (2003). Frameworks and indicators for assessing progress in integrated

6 coastal management initiatives. Ocean and Coastal Management, 46(3), 347-361.

7 Pereira, L. C. C., Guimarães, D. de O, Costa, R. M. da, \& Souza-Filho, P. W. M. (2007).

8 Use and Occupation in Bragança Littoral, Brazilian Amazon. Journal of Coastal Research,

9 SI 50, 1116-1120.

10 Pereira, L. C. C., Oliveira, S. M. O. de, Costa, R. M. da, Costa, K. G. da, \& Vila-Concejo,

11 A. (2013a). What happens on an equatorial beach on the Amazon coast when La Niña 12 occurs during the rainy season? Estuarine, Coastal and Shelf Science (Print), 135, 11613127.

14 Pereira, L. C. C., Silva, N. I. S. da, Costa. R. M., Asp, N. E., Costa, K. G. da, \& Vila15 Concejo, A. (2012). Seasonal changes in oceanographic processes at an equatorial 16 macrotidal beach in northern Brazil. Continental Shelf Research, 43, 95-106.

17 Pereira, L. C. C., Vila-Concejo, A. \& Short, A. D. (2016). Coastal Morphodynamic 18 Processes on the Macro-Tidal Beaches of Pará State Under Tidally-Modulated Wave 19 Conditions. In A. D. Short and A. H.F. Klein (Eds.), Brazilian Beach Systems (in press). 20 Coastal Research Library.

21 Pereira, L. C. C., Vila-Concejo, A., \& Short, A. D. (2013b). Influence of subtidal sand 22 banks on tidal modulation of waves and beach morphology in Amazon macrotidal 23 beaches. Journal of Coastal Research, SI 65 (2), 1821-1826.

24 Pereira, L. C. C., Vila-Concejo, A., Costa, R. M. da, \& Short, A. D. (2014). Managing 25 physical and anthropogenic hazards on macrotidal Amazon beaches. Ocean and Coastal Management, 96, 149-162. 
1 Pessoa, R. M. C., Pereira, L. C. C., Sousa, R.C., Magalhães, A., \& da Costa, R.M. (2013).

2 Recreational carrying capacity of an amazon macrotidal beach during vacation periods.

3 Journal of Coastal Research, SI 65, 1027-1032.

4 Pinto, K. S. T., Pereira, L. C. C., Vila-Concejo, A., Gorayeb, A., Sousa, R. C. de, \& Costa,

5 R. M. da. (2011). Effects of the lack of coastal planning on water quality and land use on a

6 macrotidal beach (Atalaia, Pará) in the amazon region. Journal of Coastal Research, SI $7 \quad 64,1401-1405$.

8 Polette, M., \& Raucci, G. (2003). Methological Proposal for Carrying Capacity Analysis in

9 Sandy Beaches: A Case Study at the Central Beach of Balneário Camboriú- SC- Brazil.

10 Journal of Coastal Research, SI 35, 94-103.

11 Praveena, S. M., Chen, K. S., \& Ismail, S. N. S. (2013). Indicators of microbial beach water

12 quality: preliminary findings from Teluk Kemang beach, Port Dickson (Malaysia). Marine 13 Pollution Bulletin, 76, 417-419.

14 Saarinen, J. (2006). Traditions of sustainability in tourism studies. Annals of Tourism 15 Research, 33, 1121-1140.

16 Saveriades, A. (2000). Establishing the social tourism carrying capacity for the tourist

17 resorts of the east coast of the Republic of Cyprus. Tourism Management, 21, 147-156.

18 Segrado, R., Muñoz, A. P., \& Arroyo, L. (2008). Medición de la capacidad de carga 19 turística de Cozumel. El Periplo Sustentable, 13, 33-61.

20 Silva, C. P., da. (2002). Beach Carrying Capacity Assessment: How Important is it? 21 Journal of Coastal Research, SI 56, 190-197.

22 Silva, I. R. da, Pereira, L. C. C., Sousa, R. C., Oliveira, S. M. O de, Guimarães, D. de O., \& 23 Costa, R. M. da. (2011a). Amazon Beaches (São Luís, Brazil): Recreational Use, 24 Environmental Indicators, and Perception of Beachgoers. Journal of Coastal Research, SI $25 \quad 64,1287-1291$. 
1 Silva, I. R. da, Pereira, L. C. C., Trindade, W.N., Magalhães, A., \& Costa, R. M. (2013).

2 Natural and anthropogenic processes on the recreational activities in urban Amazon

3 beaches. Ocean \& Coastal Management, 76, 75-84.

4 Silva, J. S., Leal, M. M. V., Araújo, M. C. B., Barbosa, S. C. T., \& Costa, M. F. (2008).

5 Spatial and Temporal Patterns of Use of Boa Viagem Beach, Northeast Brazil. Journal of

6 Coastal Research, 24 (1A), 79-86.

7 Silva, N. I. S. da, Pereira, L. C. C., Vila-Concejo, A., Gorayeb, A., Sousa, R.C. de, Asp, N.

8 E., \& Costa, R. M. da. (2011b). Natural and social conditions of Princesa, a macrotidal

9 sandy beach on the Amazon Coast of Brazil. Journal of Coastal Research, SI 64, 1979101983.

11 Sousa, R. C., Pereira, L. C. C., \& Costa, R. M. (2013). Water quality at touristic beaches

12 on the Amazon coast. Journal of Coastal Research, SI 65, 1057-1062.

13 Sousa, R. C., Pereira, L. C. C., Costa, R. M., \& Jiménez, J. A. (2014). Tourism carrying 14 capacity on estuarine beaches in the Brazilian Amazon region. Journal of Coastal 15 Research, SI 70, 545-550.

16 Sousa, R. C., Pereira, L. C. C., Silva, N. I. S., Oliveira, S. M. O. de, Pinto, K. S. T., \& 17 Costa, R. M. da. (2011). Recreational carrying capacity of three Amazon macrotidal 18 beaches during the peak vacation season. Journal of Coastal Research, SI 64, 1292-1296.

19 Souza-Filho, P. W. M., Martins, E. S. F., \& Costa, F. R. (2006). Using mangroves as a 20 geological indicator of coastal changes in the Bragança macrotidal flat, Brazilian Amazon:

21 A remote sensing data approach. Ocean and Coastal Management, 49, 462-475.

22 Strickland, J. D. H., \& Parsons, T. R. A. (1968). The Practical Handbook of Seawater 23 Analysis. Journal of the Fisheries Research Board of Canada, 167, 1-311.

24 Strickland, J. D. H., \& Parsons, T. R. A., 1977. A Practical Handbook of Seawater 25 Analysis. (2nd ed.). Fisheries Research Board of Canada 1972, Ottawa. Bulletin 167. 
1 Szlafsztein, C. (2012). Natural disasters management in the Brazilian Amazon: an analysis

2 of the States of Acre, Amazonas and Pará. In S. Cheval (Org.). Natural Disasters. Zagreb:

3 INTECH.

4 Szlafsztein, C. F. (2009). Indefinições e Obstáculos no Gerenciamento da Zona Costeira

5 do Estado do Pará, Brasil. Revista da Gestão Costeira Integrada, 9(2), 47-58.

6 Szlafsztein, C., \& Sterr, H. (2007). A GIS-based vulnerability assessment of coastal natural

7 hazard, state of Pará, Brazil. Journal Coastal Conservation, 11, 53-66.

8 UNEP/PAP. (1997). Guidelines for carrying capacity assessment for tourism in

9 Mediterranean coastal areas. Turkey, Priority Actions Programme Regional Activity

10 Centre. Split.

11 Vila-Concejo, A., Hughes, M. G., Short, A. D., \& Ranasinghe, R. (2010). Estuarine

12 shoreline processes in a dynamic low-energy system. Ocean Dynamics, 60(2), 285-298.

13 WTO, World Tourism Organization. (1981). Saturation of Tourist Destinations: Report of 14 the Secretary General, Madrid.

15 Zacarias, D. A., Williams, A. T., \& Newton, A. (2011). Recreation carrying capacity 16 estimations to support beach management at Praia de Faro, Portugal. Applied Geography, $17 \quad 31,1075-1081$. 


\section{FIGURE CAPTIONS}

3 Figure 1. Study area location. (A) South America and (B-D) part of Pará state, showing

4 Murubira, Colares and Marudá beaches (D), and (E-G) photographs of the study beaches.

5 Figure 2. Mean difference between the high water level (HWL) and the low water level

6 (LWL) of each study beach during neap tides.

7 Figure 3. (A) Beachgoers concentrated near the main access road to Marudá beach. (B)

8 Beachgoer distribution depending on the tidal elevation on Colares beach. (C) Promenade

9 at Murubira beach occupied by beachgoers (street party).

10 Figure 4. Coastlines of the study beaches: (A) Colares (Obtained from:

11 http://www.mapio.cz/a/14390684/); $\quad$ (B) Marudá (Obtained from:

12 http://www.portalturismobrasil.com.br/atracao/6143/Praia-do-Maruda); and (C) Murubira

13 (Obtained from: http://www.ormnews.com.br/noticia.asp?=662130). 
Table 1. Summary of the procedures used to compile each index. *Based on CONAMA (274/2000) criteria.

\begin{tabular}{|c|c|c|c|c|}
\hline Index & Variable & Data & Frequency & Method \\
\hline $\begin{array}{l}\text { Physical Carrying } \\
\text { Capacity }\end{array}$ & $\begin{array}{l}\text { Area/ } \\
\text { User density }\end{array}$ & $\begin{array}{l}\text { Field campaigns/ } \\
\text { Literature review }\end{array}$ & Every $1 \mathrm{~h}$ & $\begin{array}{l}\text { Measurement of area/ } \\
\text { Counting beachgoers and Literature review }\end{array}$ \\
\hline & Thermotolerant colifoms* & Water samples & Every $3 \mathrm{~h}$ & APHA and CONAMA \\
\hline Water Quality & Number of sewage outlets ${ }^{*}$ & Direct observation & $\begin{array}{l}\text { Once per } \\
\text { field } \\
\text { campaign }\end{array}$ & Counting sewage outlets \\
\hline $\begin{array}{l}\text {-Physical-chemical } \\
\text { component }\end{array}$ & $\begin{array}{l}\text { Dissolved Oxygen* } \\
\mathrm{pH}^{*} \\
\text { Nitrite* }^{*} \\
\text { Nitrate* }^{*} \\
\text { Total Phosphorus }\end{array}$ & Water samples & Every 3 hours & $\begin{array}{l}\text { Winkler method (Strickland and Parsons 1968) } \\
\text { pHmeter } \\
\text { Strickland and Parsons (1972) and Grasshoff et al. } \\
\text { (1983) } \\
\text { Strickland and Parsons (1972) and Grasshoff et al. } \\
\text { (1983) } \\
\text { Strickland and Parsons (1972) and Grasshoff et al. } \\
\text { (1983; 1999) }\end{array}$ \\
\hline $\begin{array}{l}\text { - Visual aspects of the } \\
\text { beach }\end{array}$ & $\begin{array}{l}\text { Oils/fats } \\
\text { Floating debris } \\
\text { Solid residues } \\
\text { Sand odors } \\
\text { Turbidity }\end{array}$ & Direct observation & $\begin{array}{l}\text { Once per } \\
\text { field } \\
\text { campaign }\end{array}$ & Check list \\
\hline Ecological Conditions & Ecological features & Direct observation & $\begin{array}{l}\text { Once per } \\
\text { field } \\
\text { campaign }\end{array}$ & Check list \\
\hline Services & Services and infrastructure & Direct observation & $\begin{array}{l}\text { Once per } \\
\text { field } \\
\text { campaign }\end{array}$ & Check list \\
\hline
\end{tabular}


Table 2. The RCC calculated for each beach, and the values of the respective PCC and correction factors

\section{BEACHES}

\begin{tabular}{lccc} 
RCC & Colares & Marudá & Murubira \\
\hline Total Area ${\left(\mathbf{m}^{2}\right)}^{2}$ & 52,033 & 123,900 & 22,400 \\
Useable Area $\left(\mathbf{m}^{2}\right)$ & 27,825 & 67,113 & 16,000 \\
PCC (persons) & 2319 & 6711 & 1600 \\
Water Quality & 0.8 & 0.0 & 0.3 \\
Environmental Quality & 0.95 & 0.85 & 0.85 \\
Ecological Quality & 0.87 & 0.67 & 0.73 \\
Quality of Services & 0.71 & 0.8 & 0.8 \\
\hline RCC (persons) & 1089 & 0 & 238
\end{tabular}


Table 3. Water and Environmental quality scores for each study beach.

\begin{tabular}{|c|c|c|c|}
\hline \multirow{2}{*}{ VARIABLE } & \multicolumn{3}{|c|}{ BACTERIOLOGICAL SCORE } \\
\hline & Colares & Marudá & Murubira \\
\hline \multirow[t]{2}{*}{ Termotolerant Coliforms } & 0.8 & 0 & 0.3 \\
\hline & \multicolumn{3}{|c|}{ PHYSICAL-CHEMICAL SCORE } \\
\hline VARIABLE & Colares & Marudá & Murubira \\
\hline Dissolved oxygen & 1 & 1 & 1 \\
\hline $\mathrm{pH}$ & 1 & 1 & 1 \\
\hline Nitrites & 1 & 1 & 1 \\
\hline Nitrates & 1 & 1 & 1 \\
\hline \multirow[t]{2}{*}{ Total Phosphorus } & 1 & 1 & 1 \\
\hline & \multicolumn{3}{|c|}{ VISUAL ASPECT SCORE } \\
\hline VARIABLE & Colares & Marudá & Murubira \\
\hline Oils and fats & 1 & 1 & 1 \\
\hline Floating debris & 1 & 0.6 & 0.6 \\
\hline Solid residues in the sand & 0.6 & 0.6 & 0.6 \\
\hline Sand odors & 1 & 0.6 & 0.6 \\
\hline Water turbidity & 0.6 & 0.6 & 0.6 \\
\hline
\end{tabular}


Table 4. Ecological Quality scores for each study beach.

\begin{tabular}{lccc}
\hline \multirow{2}{*}{ VARIABLE } & \multicolumn{3}{c}{ BEACH } \\
\cline { 2 - 4 } & Colares & Marudá & Murubira \\
\hline Degradation of dunes & 1 & 0.8 & 0.6 \\
Degradation of mangroves & 1 & 0.6 & 0.8 \\
Risk of coastal erosion & 0.6 & 0.6 & 0.8 \\
\hline
\end{tabular}


Table 5. Quality of Services scores for each study beach.

\begin{tabular}{lccc}
\hline \multirow{2}{*}{ VARIABLE } & \multicolumn{3}{c}{ BEACH } \\
\cline { 2 - 4 } & Colares & Marudá & Murubira \\
\hline Public restrooms & 0.6 & 0.6 & 0.6 \\
Waste bins & 0.6 & 0.8 & 0.8 \\
Parking & 0.6 & 0.8 & 0.8 \\
Safety & 1 & 1 & 1 \\
Accommodation & 0.8 & 0.8 & 0.8 \\
Bars and restaurants & 0.8 & 0.8 & 0.8 \\
Accessibility & 0.6 & 0.8 & 0.8 \\
\hline
\end{tabular}




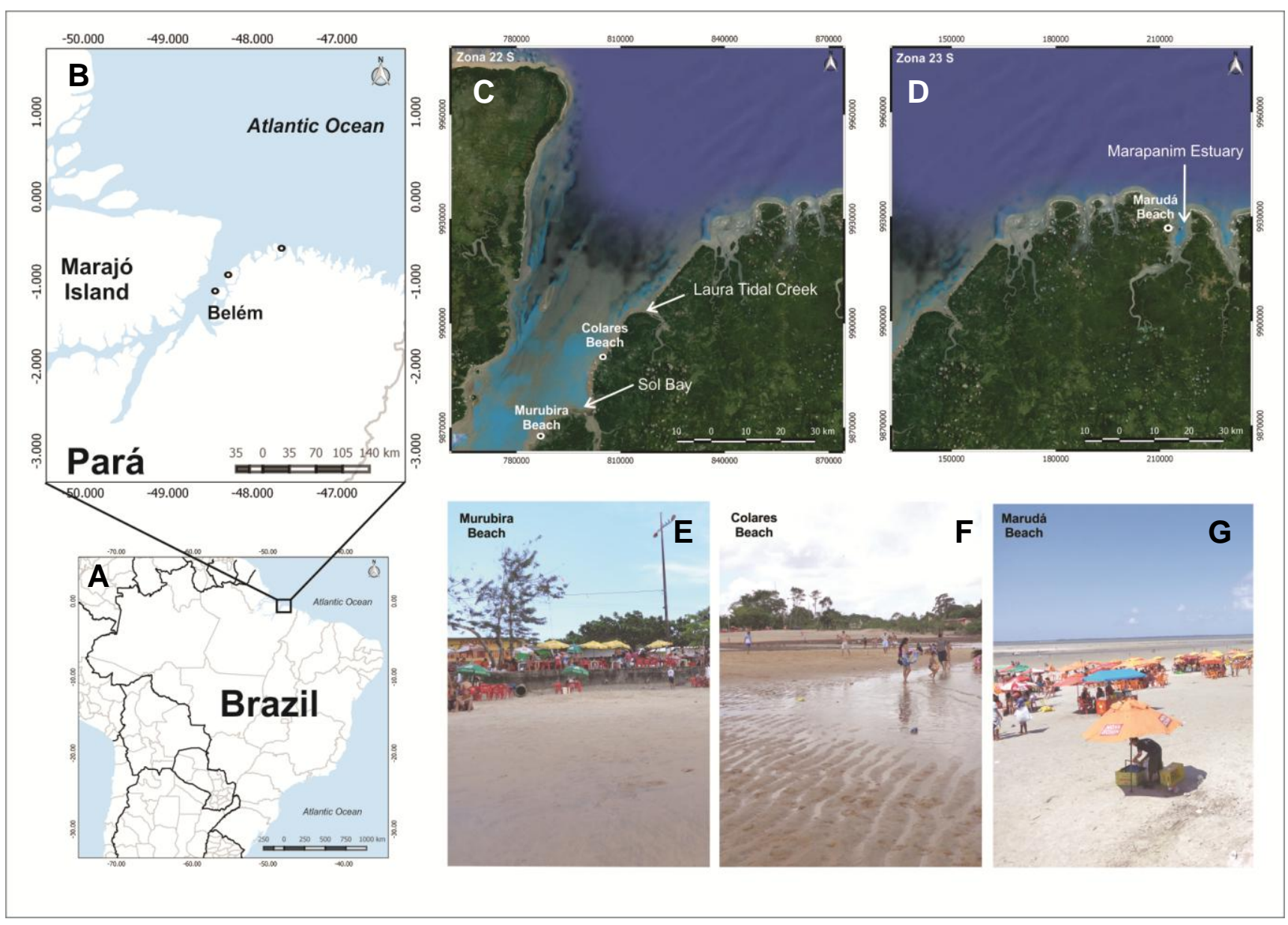

Figure 1. Study area location. (A) South America and (B-D) part of Pará state, showing Murubira, Colares and Marudá beaches (D), and (E-G) photographs of the study beaches. 


\begin{tabular}{|c|c|c|c|c|c|}
\hline \multicolumn{2}{|c|}{$\begin{array}{c}\text { Colares } \\
\text { BACKSHORE }\end{array}$} & \multicolumn{2}{|c|}{$\begin{array}{c}\text { Marudá } \\
\text { PROMENADE }\end{array}$} & \multicolumn{2}{|c|}{$\begin{array}{c}\text { Murubira } \\
\text { PROMENADE }\end{array}$} \\
\hline \multirow[t]{2}{*}{$\begin{array}{l}\text { Useful Lenght } \\
\quad(300 \mathrm{~m})\end{array}$} & $\begin{array}{l}\text { Total Lenght } \\
\quad(561 \mathrm{~m}) \\
\mathrm{HWL}\end{array}$ & $\begin{array}{l}\text { Useful Lenght } \\
\quad(650 \mathrm{~m})\end{array}$ & $\begin{array}{l}\text { Total Lenght } \\
(1200 \mathrm{~m})\end{array}$ & $\begin{array}{l}\text { Useful Lenght } \\
(1000 \mathrm{~m})\end{array}$ & \multirow{2}{*}{$\begin{array}{l}\text { Total Lenght } \\
\begin{array}{|l}(1400 \mathrm{~m}) \\
\mid\end{array}\end{array}$} \\
\hline & & & & $\begin{array}{c}\text { Useful width } \\
(16 \mathrm{~m})\end{array}$ & \\
\hline $\begin{array}{l}\text { Useful width } \\
(92.8 \mathrm{~m})\end{array}$ & $\begin{array}{c}\text { Total width } \\
(111 \mathrm{~m})\end{array}$ & $\begin{array}{l}\text { Useful width } \\
\text { (103 m) }\end{array}$ & $\begin{array}{l}\text { Total width } \\
(144 \mathrm{~m})\end{array}$ & & \\
\hline$\dot{\text { Muddy }} \cdot \dot{S}$ & diments $L W L$ & $\therefore \quad \cdot$ & nts $\because \dot{\bullet}$ & & \\
\hline
\end{tabular}

Figure 2. Mean difference between the high water level (HWL) and the low water level (LWL) of each study beach during neap tide. 

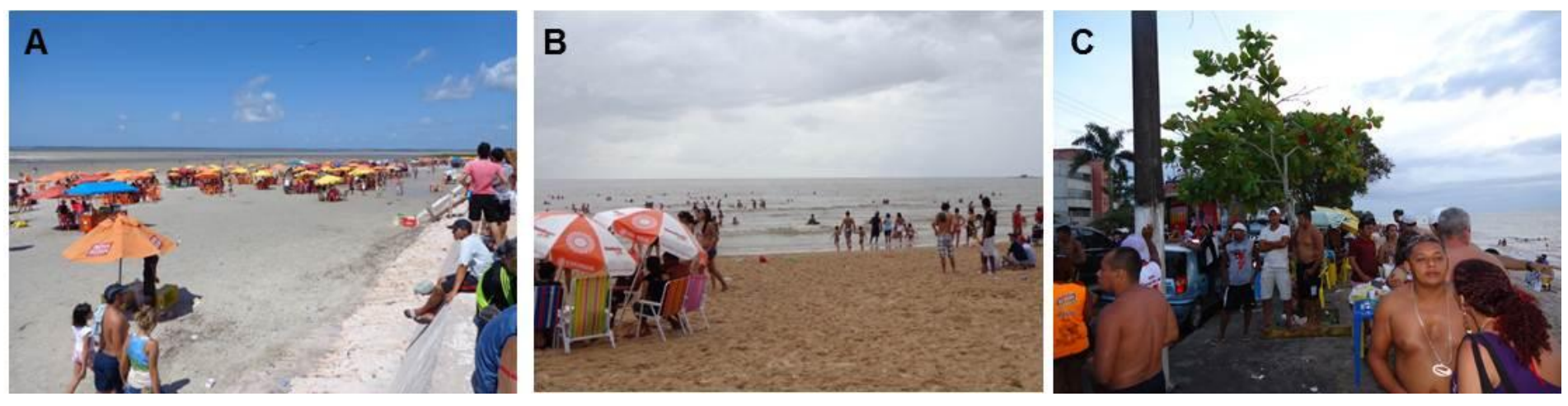

Figure 3. (A) Beachgoers concentrated near the main access road to Marudá beach. (B) Beachgoer distribution depending on the tidal elevation on Colares beach. (C) Promenade at Murubira beach occupied by beachgoers (street party). 

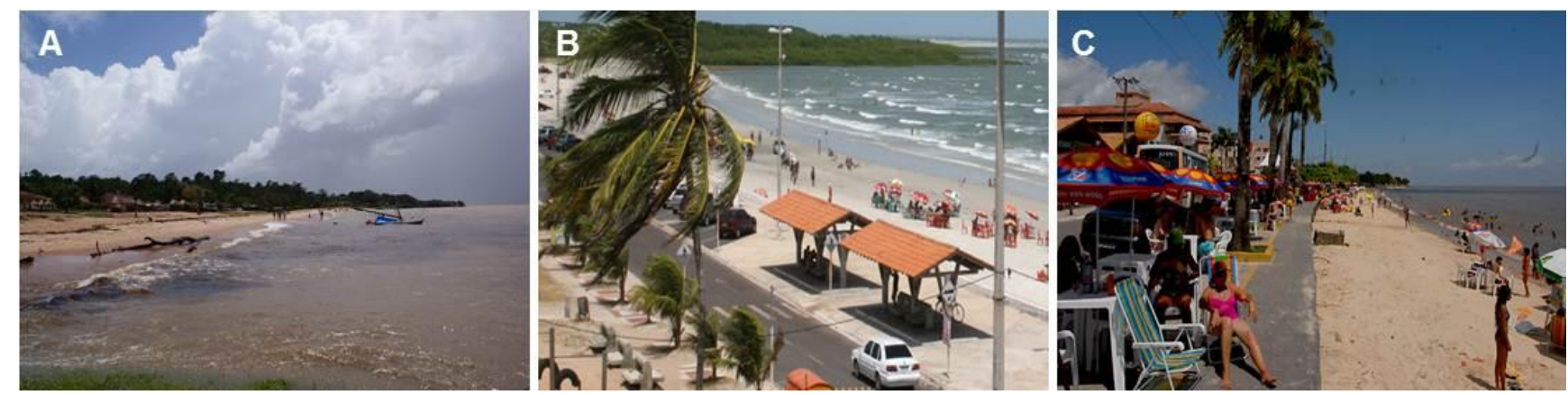

Figure 4. Coastlines of the study beaches: (A) Colares (Obtained from: http://www.mapio.cz/a/14390684/); $\quad$ (B) Marudá (Obtained from: http://www.portalturismobrasil.com.br/atracao/6143/Praia-do-Maruda); and (C) Murubira (Obtained from: http://www.ormnews.com.br/noticia.asp?=662130). 